\title{
A reação dos evangélicos ao novo Código Civil
}

Ricardo Mariano*

Existem os que vêem no novo Código, no que se refere às igrejas (associações), uma espécie de perseguição do governo. São leis, dizem, que visam à intromissão governamental na administração eclesiástica com o objetivo de dificultar o crescimento das igrejas. Referindo-se a esse grupo, muito bem retratou o pastor Elias Werneck, redator da Revista Administração Eclesiástica, edição JUERP, quando disse: "Questionamentos estão sendo levantados, alguns dos quais meio na base do quase terrorismo ou uma espécie de escatologismo".

Tantas novidades têm causado polêmica e preocupado boa parte da liderança evangélica, além, é claro, dos crentes. Histórias de que igrejas serão fechadas, dízimos serão taxados, pastores acabarão presos e de que homossexuais terão que ser aceitos sem contestação nas comunidades cristãs podem ser ouvidas cada vez com mais freqüência após os cultos. ${ }^{2}$

* Doutor em Sociologia pela USP e professor do Programa de Pós-Graduação em Ciências Sociais da Pucrs. A pesquisa foi financiada pelo CNPq e contou com a participação de Toty Ypiranga de Souza Dantas e Manuela Schneider, bolsistas de Iniciação Científica do CNPq. Endereço: rmariano1@uol.com.br.

1 http://www.batistas.mg.org.br/obatista/junho/noticia8.htm.

2 Jornal Rio Grande Gospel, 15/3/2003, matéria intitulada “Obra de Deus, lei dos homens".

\begin{tabular}{|l|l|l|l|l|l|}
\hline Civitas & Porto Alegre & v. 6 & n. 2 & jul.-dez. 2006 & p. 77-99 \\
\hline
\end{tabular}




\section{Introdução}

O artigo analisa a reação evangélica ao novo Código Civil, baseada em pesquisa empírica realizada por meio de entrevistas semidiretivas com pastores e parlamentares evangélicos, do exame de material da imprensa secular sobre o tema e da investigação de livros, jornais, revistas e sites desses religiosos.

O novo Código Civil, que passou a vigorar em 11 de janeiro de 2003, fixou novas regras para o funcionamento e a organização das associações religiosas no país. Sua implementação, que deveria ocorrer até 10 de janeiro de 2004, tenderia a ampliar o controle jurídico-político do Estado brasileiro e a resultar na realização de mudanças significativas nas organizações religiosas, principalmente naquelas, como as pentecostais, cujos estatutos e funcionamento efetivo acham-se mais distantes das disposições contidas nas novas regras. As mudanças não se limitariam tão-somente à realização de pontuais e breves alterações estatutárias. Extrapolariam, com efeito, o mero acato de simples formalidades legais e burocráticas. Só por isso já seria de se esperar alguma movimentação evangélica para lidar com (ou se adaptar) a nova situação jurídica. Temendo efeitos danosos os mais diversos sobre suas igrejas, lideranças evangélicas encabeçaram uma enérgica e concertada reação às regras do Código que as afetavam. Por meio da constante romaria de líderes denominacionais à Brasília, de sua mobilização nacional e da articulação da Frente Parlamentar Evangélica no Congresso Nacional, a reação evangélica resultou, como veremos, na alteração do Código, desobrigando as igrejas da exigência de efetuarem as mudanças inicialmente previstas pela lei.

Ao longo de 2002 e 2003, lideranças pentecostais e protestantes de inúmeras igrejas e entidades para-eclesiásticas - assessoradas por advogados, juízes e desembargadores evangélicos - realizaram dezenas de encontros, simpósios, seminários, cursos, conferências e debates por todo o país para discutir, esclarecer e compreender as implicações e exigências dos dispositivos legais fixados pelo novo Código Civil para as associações religiosas. Tamanha mobilização resultou não apenas da vigência da nova legislação e da imperativa e urgente necessidade de se ajustar a ela, mas também da própria novidade das regras do Código. Num primeiro momento, nesse meio religioso predominou a predisposição à submissão formal às novas normas, como veremos. Tratou-se, de todo modo, de uma submissão resignada, cumpre frisar. Mas, logo em seguida, o assunto foi se tornando cada vez mais 
polêmico, controverso, gerando interpretações conspiratórias e, por fim, resultando na proliferação de uma boataria alarmista nesse meio religioso em torno e a respeito do Código Civil. Taxação de dízimos, confisco de bens, prisão de pastores, fechamento de igrejas, intervenção estatal na administração eclesiástica, cerceamento da liberdade religiosa, obrigatoriedade de oficiar casamentos homossexuais, dentre outras medidas e sanções, compuseram os principais temores desses religiosos com a promulgação e implementação da nova lei.

A disposição inicial pela submissão não decorreu apenas do temor de vir a padecer das conseqüências da infração da lei. Respaldou-se também numa certa interpretação literalista da Bíblia, reforçada, em parte, pelo positivismo jurídico de seus expoentes. Três advogados evangélicos autores de livros ${ }^{3}$ sobre o Código, por exemplo, foram unânimes em defender a sujeição das igrejas ao novo Código Civil. Para tanto, lançaram mão de passagens bíblicas clássicas para legitimar e estimular a obediência às autoridades. $\mathrm{O}$ batista Gilberto Garcia (2003, p. 20) defendeu: "Precisamos continuar a cumprir a máxima de Jesus: 'Dai a César o que é de César e a Deus o que é de Deus' (Mt 22.21)". David Tavares Duarte (2003, p. 3), pastor da Assembléia de Deus, cita Romanos 13: 1-2, passagem em que o apóstolo Paulo, tornando a autoridade humana derivada da e legitimada pela vontade divina, exorta: "Todo homem esteja sujeito às autoridades superiores; porque não há autoridade que não proceda de Deus; e as autoridades que existem foram por ele instituídas. De modo que aquele que se opõe à autoridade, resiste à ordenação de Deus; e os que resistem trarão sobre si mesmos condenação". Sem dar qualquer margem à opção pela desobediência legal, Cícero Duarte (2003, p. 13), assessor jurídico da Associação Evangélica Brasileira (Aevb), remeteuse à passagem bíblica de 1 Pedro 2: 13: "Por causa do Senhor, sujeitem-se a toda autoridade constituída entre os homens...".

Apesar dessa sujeição resignada, não faltavam motivos para esses religiosos estarem de sobreaviso quanto a eventuais pretensões controlistas por

Advogados evangélicos publicaram pelo menos quatro livros sobre as disposições do novo Código Civil a respeito das associações religiosas: Igrejas na mira da lei, de Cícero Augusto Gonçalves Duarte; A igreja e o novo Código Civil: as mudanças e outras considerações jurídicas sobre a prática eclesiástica, de David Tavares Duarte; O novo Código Civil e as igrejas, de Gilberto Garcia; $O$ novo Código Civil e a igreja: Impactos e implicações, do presbiteriano Odilon Alexandre Silveira Marques Pereira. 
parte do Estado, mesmo que para tanto levassem em consideração apenas a crescente atividade reguladora do estado sobre áreas anteriormente consideradas privadas, como destaca Burity (2001). Mas a história recente dos pentecostais no país permitia adicionar ainda outras ilações nesse sentido. Haja vista que os conflitos e escândalos protagonizados por líderes pentecostais nos anos 80 e 90 resultaram na emergência de pressões sociais para que se ampliasse o controle estatal sobre os grupos religiosos no Brasil. ${ }^{4}$ Uma enorme demanda controlista irrompeu em meados dos anos 90, motivada, sobretudo, pelas acirradas controvérsias em torno do "chute na santa" e da divulgação do vídeo em que o bispo Edir Macedo aparecia, durante intervalo de um jogo de futebol com membros da cúpula da igreja, ensinando, de modo debochado e em meio a termos chulos, pastores e bispos a serem mais agressivos, persuasivos e eficazes na arrecadação de dízimos e ofertas. Por todo o país, diversos agentes e setores sociais, mobilizados pela controvérsia e pela estrondosa e prolongada repercussão do "chute" e do vídeo, passaram a cobrar, em uníssono, de modo enfático e em variadas instâncias, maior controle, fiscalização e punição dos líderes e grupos religiosos envolvidos nos incidentes e escândalos. ${ }^{5}$ Demandavam maior regulação e controle estatal das reli-

4 Quanto a isso, basta elencar alguns de seus protagonistas: Igreja Deus é Amor e seu fundador missionário David Miranda, Igreja Universal do Reino de Deus e o bispo Edir Macedo, Igreja Renascer em Cristo e seu casal dirigente, apóstolo Estevam Hernandes e bispa Sônia Hernandes (Campos, 1998; Mariano, 1999; Giumbelli, 2000). Por certo, não foram apenas tais grupos e personagens religiosos que estamparam manchetes sensacionalistas e deram ensejo a inquéritos policiais, a processos judiciais e até a prisões temporárias. Parlamentares evangélicos também foram acusados de vender votos em troca de verbas, emissoras de rádio etc. (Pierucci, 1989; Mariano e Pierucci, 1992; Freston, 1993). Alguns deles tiveram, inclusive, o mandato cassado pelo Congresso Nacional. O escândalo de maior impacto ocorreu em 2006, quando um senador e 28 deputados federais evangélicos, quase a metade da bancada evangélica, foram acusados, pela CPMI das Sanguessugas, de fazer parte da máfia das sanguessugas.

5 Na hierarquia católica, o teólogo Jesús Sánches Hortal assegura que "a tentação mais comum [das lideranças eclesiásticas], diante dessa realidade pluralista, é a de invocar a intervenção das autoridades civis, a fim de que reprimam as 'seitas', como nocivas ao bem comum. Muitos desejariam uma legislação repressora de certos comportamentos que são vistos como enganadores e destrutores da fé" (Hortal, 2000, p. 87). Portanto, vê-se que ainda hoje a liberdade religiosa - levada, segundo Hortal, "até as suas últimas conseqüências" no Brasil - é encarada, nas palavras do teólogo, como "algo dramático" pela hierarquia católica (Hortal, p. 87, 90). Para as outras religiões, em contraste, não há nada mais sagrado que a lei constitucional assegurando a liberdade religiosa, que lhes permitiu ingressar, aflorar e crescer em solo brasileiro. 
giões em geral, em especial da Igreja Universal. Não se sabe efetivamente se tais fatos e demandas influenciaram os elaboradores do novo Código Civil em sua decisão de classificar os grupos religiosos como associações, impondo-lhes, assim, novas exigências legais. Para muitos evangélicos, porém, não pairava a menor dúvida de que o Estado pretendia, por meio da nova legislação, expandir seu poder, seu controle e sua fiscalização sobre as igrejas evangélicas. David Tavares Duarte, pastor e advogado, previa: "o novo Código deve aumentar a fiscalização do Estado" sobre as igrejas. ${ }^{6}$ Já Melquisedeque Chagas, pastor e consultor eclesiástico da Evangelho Quadrangular, vaticinava: "haverá uma fiscalização enérgica" das igrejas por parte do Estado.

Para nossos propósitos imediatos, importa frisar que os conflitos e escândalos que macularam a imagem dos evangélicos, ao lado de preconceitos e pequenas discriminações experimentados cotidianamente por adeptos desse grupo religioso, reativam freqüentemente a memória persecutória e reiteram narrativas e testemunhos sobre a velha "perseguição" católica e policial aos pentecostais no Brasil. ${ }^{8}$ Cada novo conflito, cada nova acusação e cada novo escândalo envolvendo esses religiosos servem, portanto, de ensejo e pretexto para que suas lideranças tratem de reatualizar suas memórias e narrativas para caracterizar uma identidade religiosa, em parte, marcada pelo ressentimento de minoria religiosa menosprezada, discriminada e perseguida. Conforme o contexto, os conflitos e os interesses em jogo, essa identidade vai sendo remodelada e estrategicamente acionada por seus líderes eclesiásticos e políticos. Cumpre observar que ela só tem sido reelaborada e mobilizada eficazmente pelo fato de que as representações identitárias de expressiva parcela desses religiosos persistem, defensiva e reiteradamente, em bater nas teclas da existência de discriminação aos evangélicos e de limitações à sua liberda-

Eclésia, n. 85, 2003, p. 31.
Eclésia, n. 85, 2003, p. 32.

Proposta no Concílio Plenário Brasileiro, de 1939, e implementada pelo Departamento de Defesa da Fé, a oposição católica ao protestantismo levada a cabo em nome da defesa da "nação católica" tivera início no Estado Novo, que também se pretendia intérprete e promotor dos interesses da nação brasileira (Rolim, 1985, p. 72, 82). Como a concorrência religiosa, apesar da ferrenha perseguição católica, só fez crescer desde então, em 1953 a Igreja lançou nova ofensiva, criando o Secretariado Nacional para a Defesa da Fé e da Moralidade, cujos objetivos eram os de vigiar "a marcha das falsas religiões, condenar movimentos e falsas idéias" e "a expansão da imoralidade e da amoralidade na vida pública e particular" (Mainwaring, 1989, p. 54). 
de religiosa. Isto é, sua persistência decorre não apenas de sua disposição estratégica de mantê-la viva e dotada de eficácia mobilizadora, mas depende também da existência de certa plausibilidade, por mínima que seja. É, pois, da posição e da perspectiva de "gatos escaldados" que muitos deles, em especial pastores, reverendos, bispos e políticos evangélicos, interpretaram o potencial impacto controlista e, pior ainda a seu ver, discriminador do novo Código Civil sobre as igrejas evangélicas.

De modo que cumpre considerar tanto as demandas controlistas recentes como suas representações identitárias de minoria discriminada para perceber que a mobilização, os temores, os boatos alarmistas em torno do Código Civil basearam-se na convicção de muitos líderes evangélicos de que sua liberdade religiosa encontrava-se sob forte risco de ser cerceada pela intervenção indevida e espúria do Estado. Situação grave que, a seu ver, requeria pronta e eficiente reação. E foi justamente a bandeira da liberdade religiosa - que desde os anos 80 vem sendo sistematicamente acionada para justificar e legitimar seu ingresso e participação na política partidária e, por conseqüência, para mobilizar os irmãos a votarem nos irmãos - que acabou por ser novamente empunhada por este grupo religioso, desta vez para alterar o Código Civil.

\section{As mudanças do Código e suas implicações para as igrejas}

No Código Civil de 1916, as organizações religiosas eram classificadas à parte como "sociedades religiosas". Em princípio, sobre elas se exercia menor controle legal que o propiciado pelo novo Código, que passou a classificá-las como "associações", definindo-as, no artigo $53^{\circ}$, como constituídas pela "união de pessoas que se organizem para fins não econômicos". O que as define, portanto, é sua finalidade não econômica. Com isso, do ponto de vista legal, sua distintividade religiosa, reconhecida no velho Código Civil ao classificá-las à parte como "sociedades religiosas", desaparece e deixa de ser legitimada pelo Estado. Em termos jurídicos, elas passaram a não diferir mais de qualquer outra associação não-religiosa. De modo que, independentemente das particularidades inerentes a e decorrentes de seu caráter e propósito religiosos, elas deveriam se submeter da mesma forma e às mesmas disposições legais que, por exemplo, associações de bairro, clubes de futebol, entidades filantrópicas, entre outras associações. Pode-se inferir que o tratamento legal 
indiferenciado dispensado pelo novo Código às diferentes associações sem fins lucrativos, incluídas nesse rol as religiosas, contém notório viés secularizante, sujeitando os grupos religiosos à normatividade jurídica sem conferirlhes nenhuma distintividade ou privilégio.

Dado que o novo Código Civil instituiu apenas associações, sociedades e fundações como pessoas jurídicas de direito privado, para muitos evangélicos, em especial os que posteriormente recusaram a classificação das agremiações religiosas como associações, as igrejas teriam ficado fora da lei, ou num "limbo jurídico/legal", como definiu o Deputado Federal Paulo Gouvêa (PL-RS), autor do primeiro projeto de lei para alterar o Código Civil.

Evangélicos de diferentes igrejas, de modo geral, ficaram descontentes com a mudança legal. Mas, como frisamos, disseminaram-se insatisfações e temores mais preocupantes a respeito dos efeitos da nova legislação que o mero mal-estar. No fórum de debates do JesusSite ${ }^{9}$, um participante indaga: "Afinal, há ou não uma 'conspiração' para que cada vez mais a igreja seja submetida ao Estado?" Miguel Reale, supervisor da comissão elaboradora e revisora do novo Código Civil, em artigo publicado em $O$ Estado de S. Pau$l o$, dia 5 de julho de 2003, reconhece o problema: "As relações entre o Estado e a Igreja têm criado, no Brasil, problemas às vezes de difícil solução, como está acontecendo com o novo Código Civil, acusado de ter reduzido as Igrejas a meras 'associações civis', sujeitas a mandamentos estatais." Essas acusações foram efetuadas sobretudo por pentecostais. David Tavares Duarte (2003, p. 2-3), presidente da comissão jurídica da Convenção Geral das Assembléias de Deus no Brasil, constata que "a igreja como associação civil [...], num mundo temporal, cada vez mais secular, pelos seus legítimos representantes há de entender o espírito da secularização que impera no momento e, por conseguinte, responder através de uma estratégia racional, que sua bandeira é de ordem e respeito ao legal" (grifos meus). Não obstante rejeite o "espírito de secularização", o pastor assembleiano mostrou-se resignado e disposto a respeitar a nova ordem jurídica. Essa, em princípio, constituiu a reação predominante nesse meio religioso.

Entre as principais inovações estatuídas pelo Código Civil está o Artigo 50. Seu objetivo precípuo consiste em disciplinar os administradores das

9 www.jesussite.com.br/forum/showmessage.asp?id=5014. 
associações "em caso de abuso de personalidade, caracterizado pelo desvio de finalidade ou pela confusão patrimonial". Na ocorrência desse abuso, o juiz pode decidir, a requerimento da parte ou do Ministério Público, que a pena incida sobre os "bens particulares dos administradores" da associação religiosa - presidente, vice-presidentes, secretários e tesoureiros. Penhora, confisco, multa e até prisão foram algumas das sanções previstas por advogados evangélicos para os responsáveis por tal delito. Para o juiz cível Leonel Carlos da Costa, do Foro de Santana, em São Paulo, se houver desvio de finalidade ou confusão do patrimônio da associação com bens particulares, "os administradores poderão pagar o prejuízo do próprio bolso, ter seus bens confiscados, ser destituídos e mesmo ir para a cadeia". ${ }^{10}$ Daí o fato de esse artigo ter constado como um dos mais temidos pelos pastores pentecostais. $\mathrm{O}$ que tornava o Artigo 50 ainda mais ameaçador para vários dirigentes evangélicos era a possibilidade de intervenção do Ministério Público, cujos poder, atuação e rigor em nossa sociedade se ampliaram muito nos últimos anos.

O Artigo 57 também causaria importantes mudanças no estatuto e no funcionamento das igrejas, ao estabelecer que "a exclusão do associado só é admissível havendo justa causa, obedecido o disposto no estatuto". Essa norma implica que o estatuto, cujo conteúdo deve ser de livre acesso a todos os associados, tem que definir objetivamente as transgressões passíveis de penalidade bem como o teor e os critérios de sua aplicação, observando-se sempre, quando aplicada a pena, o princípio da proporcionalidade. Sendo o estatuto omisso nesse aspecto, continua o texto do referido artigo, a exclusão "poderá também ocorrer se for reconhecida a existência de motivos graves, em deliberação fundamentada, pela maioria absoluta dos presentes à assembléia geral especialmente convocada para esse fim". Seu parágrafo único prevê que, uma vez decretada a exclusão, ao excluído "caberá sempre recurso à assembléia geral", que decide se a punição ao associado é procedente ou não. Mais que isso: o Código permite que o acusado, sentindo-se vítima de

10 Eclésia, n. 85, 2003, p. 31. O artigo $50^{\circ}$ do novo Código Civil é bem claro nesse ponto, ao estabelecer: "Em caso de abuso da personalidade jurídica, caracterizado pelo desvio de finalidade, ou pela confusão patrimonial, pode o juiz decidir, a requerimento da parte, ou do Ministério Público quando lhe couber intervir no processo, que os efeitos de certas e determinadas relações de obrigações sejam estendidos aos bens particulares dos administradores ou sócios da pessoa jurídica". 
discriminação ou das ações de um poder discricionário, pleiteie na Justiça reparação, inclusive indenizatória, pelos danos sofridos.

Esse artigo, com efeito, poderia servir de instrumento ou de recurso legal para inibir o autoritarismo e o abuso de poder das lideranças pastorais, ao ampliar o poder de defesa do "associado" contra o arbítrio clerical. Por consagrar o princípio de ampla defesa, David Tavares Duarte concluiu: "acabou o tempo em que as normas eram ditadas por pastores e se administrava por decreto". ${ }^{11}$ À parte tamanho otimismo com o potencial democratizante da nova legislação, cumpre enfatizar que o Código, além de conceder o direito de defesa e dilatar o poder defensivo dos leigos, facultava maior poder decisório às assembléias de membros das associações. O Artigo 60 permite que um quinto dos associados convoquem uma assembléia geral, à qual o Artigo 59 atribui a competência de eleger os administradores, aprovar as contas e, quando convocada para este fim, destituir os administradores e alterar o estatuto, exigindo-se, para tanto, o voto concorde de dois terços dos presentes à assembléia. $\mathrm{O}$ poder deliberativo dessas assembléias poderia vir a contrabalançar, nem que fosse em determinadas situações e de modo esporádico e parcial, um governo eclesiástico centralizado e pouco afeito, quando não avesso, ao exercício de regras e procedimentos democráticos. A avaliação preponderante dos advogados evangélicos era de que o Código Civil deveria estimular a democratização das igrejas evangélicas. Para o advogado Cícero Gonçalves Duarte, "as lideranças [evangélicas] precisam entender que os tempos mudaram. Não se trata de intervenção do Estado, mas de coibir abusos e gerar democracia". ${ }^{12}$ Opinião defendida igualmente pelo jurista Miguel Reale, para o qual "o Código Civil, ao disciplinar a vida das associações e das sociedades, inclusive das empresas, tem por finalidade 'democratizá-las', respeitando-lhes sua necessária autonomia".13

Cabe observar que o acusado ou exclú́do poderia pleitear também reparo indenizatório por danos morais, caso sua intimidade, sua vida privada, sua honra ou sua imagem fossem violadas, ${ }^{14}$ de acordo com o que prevê o artigo

\footnotetext{
Eclésia, n. 85, 2003, p. 32.

Eclésia, n. 85, 2003, p. 36.

O Estado de S. Paulo, 5 jul. 2003.

14 As pessoas jurídicas também têm direitos de personalidade. Direitos que se aplicam ao nome e à marca da instituição, à sua honra e imagem pública (Garcia, 2003, p. 71-72).
} 
5, inciso X, da Constituição Federal e o Artigo 21 do novo Código Civil. Em razão disso, o desembargador Ademir Paulo Pimentel, membro da igreja Batista, aconselhava que "os termos da exclusão não devem agredir a personalidade do excluído, sob pena de incidir o dever indenizatório" (Garcia, 2003, p. 48). Nesse ponto, pastor Melquisedeque Chagas, da Igreja Quadrangular, temia que "atitudes de preconceito racial ou contra homossexuais" pudessem "trazer conseqüências penais aos responsáveis legais pela igreja". ${ }^{15}$ Alarmista, o Deputado Federal Walter Pinheiro (PT-BA), por sua vez, julgava até que "antes [da alteração do Código Civil] poderíamos ser processados se recusássemos um casamento homossexual dentro da nossa igreja. Agora não mais". ${ }^{16}$ Esse foi um dos temores mais difundidos por lideranças evangélicas para desancar as exigências legais citadas. Temor que beirava o delírio, já que do ponto de vista jurídico não tinha procedência alguma. Indagado sobre a exclusão de homossexuais da igreja, o advogado evangélico Luiz Fernando Gevaerd, ponderado, afirmou:

O que não pode haver é discriminação. A igreja não pode ter nada contra o homossexual, mas pode ter contra a prática do homossexualismo. Ela não é obrigada a tolerar o que contraria as regras de fé e de prática que estão na Bíblia. Se a igreja tem um código de disciplina e lá tem uma cláusula dizendo que membros devem obedecer a regras de comportamento pautadas na Bíblia, aquele que violar a cláusula irá submeter-se a uma comissão de disciplina que vai graduar a penalidade, advertência, suspensão, exclusão. [...] Tenho o direito de discordar e condenar o homossexualismo. É uma liberdade de expressão. Não sou obrigado a concordar, não posso é discriminar. ${ }^{17}$

Outro efeito do Código Civil seria o incremento do formalismo e da burocratização da gestão denominacional. De saída, obrigava as igrejas a reformar o estatuto para adaptá-lo ao Código. O Artigo 54, sem correspondência no Código anterior, previa que o estatuto devia conter, sob pena de nulidade, as seguintes disposições: I - a denominação, os fins e a sede da associação; II - os requisitos para a admissão, demissão e exclusão dos associados; III - os direitos e deveres dos associados; IV - as fontes de recursos para sua manutenção; $\mathrm{V}$ - o modo de constituição e funcionamento dos órgãos deliberativos e administrativos; VI - as condições para a alteração das disposições estatutá-

\footnotetext{
Eclésia, n. 85, 2003, p. 32.

www.coracaodemaria.org.Br/interna.php?área=noticias\&cód_área=8\&art_cód=1293.

7 Enfoque Gospel, edição 19, ano 2, p. 14-15, fev. 2003.
} 
rias e para a dissolução. Tendo em conta a inovadora instituição do amplo direito de defesa dos leigos, o pastor e advogado David Tavares Duarte (2003, p. 10-11) argumentava que as igrejas não poderiam mais aceitar "acusação contra quem quer que seja, sem provas irrefutáveis ou a demonstração inconteste, com elementos que materializem a falta supostamente praticada". Para apurar irregularidades, defendia que deveria "ser respeitado o princípio da formalidade processual, com a coleta e produção de elementos que instruam satisfatoriamente os autos de apuração". Em caso de confissão, ela deveria ser tomada "por escrito" e "na presença de no mínimo duas testemunhas idôneas". Em suma, para obedecer ao Código Civil e não contrariar o direito de defesa dos associados, juristas evangélicos propunham que as associações religiosas incorporassem procedimentos formais e processuais comuns ao judiciário. Reforçando a burocratização da gestão das associações religiosas, o artigo sobre abuso de personalidade - que ocorre quando os administradores descumprem a finalidade da associação ao se apropriarem indevidamente de seus recursos e patrimônio - obrigava a igreja a registrar ou contabilizar toda movimentação financeira, comprovar suas receitas e despesas, manter atualizado seu inventário patrimonial, pagar os encargos trabalhistas dos funcionários, apresentar declaração anual do Imposto de Renda. De modo que a situação anterior na qual as religiões viviam e agiam "economicamente numa condição tal de non-accountability", nos termos de Flávio Pierucci (1996, p. 5), estava com os dias contados.

As médias e grandes igrejas, que possuem departamentos jurídico e contábil, por certo, não teriam maiores problemas práticos em atender a maioria de tais exigências legais. Contudo, o mesmo não deveria ocorrer com as pequenas igrejas pentecostais, que, em geral, são desprovidas de estrutura burocrática formal. Muitas delas nem sequer possuem estatuto registrado em Cartório de Registro Civil de Pessoas Jurídicas, o que, com efeito, as deixa sem existência legal. Esse problema se estende em grande medida a grupos religiosos como a Umbanda e o Candomblé, por exemplo, cujos terreiros, tendas ou comunidades de culto carecem, em sua maioria, de aparatos contábeis e burocráticos capazes de atender aos requisitos da legislação.

A preocupação com as disposições do novo Código Civil envolvia igualmente o temor do fisco. As associações religiosas não pagam impostos, apenas taxas e contribuições de melhorias. Com o novo Código, se fosse comprovado que têm fins econômicos, que auferem lucro ou que desviam 
recursos de suas atividades estritamente religiosas, seus administradores poderiam ser legalmente punidos e a igreja, segundo David Tavares, poderia perder as isenções tributárias. ${ }^{18}$ Denominações pentecostais rotineiramente tidas como mercantilistas, "supermercados da fé" e as que já foram multadas pela Receita Federal, caso da Universal, por exemplo, tinham, portanto, motivos de sobra para estar apreensivas. Mas os temores não paravam por aí. Isto é, extrapolavam o impacto direto e imediato do Código Civil. Nos meios pentecostais, temia-se (e ainda se teme) acima de tudo que o Estado brasileiro, caracterizado por sua voracidade fiscal, decidisse futuramente tributar as igrejas. Mauro Roberto Mancz, advogado da Internacional da Graça de Deus, desconfiava que "as autoridades, ao aprovarem uma lei que não distingue igrejas de outros tipos de associações, tenham um interesse implícito, que é tributar, num futuro próximo, as igrejas". ${ }^{19}$ No mesmo compasso, pastor David Tavares Duarte (2003, p. 49) observava que "não é difícil concluir que o poder executivo Federal, Estadual e Municipal, pelos seus segmentos legais, anoitecem e amanhecem pensando em criar novas fontes de arrecadação, e nesse contexto, pelo andar da carruagem, fica patente que a igreja será o próximo alvo do sedento poder governamental. Resta a igreja tomar o caminho da precaução cumprindo razoavelmente bem o seu papel de ente associativo em dia com o Governo nas suas diversas esferas de atuação, sob pena de se tornar presa fácil na futura persecução fiscal do Estado". Avaliava-se até que o pequeno comércio comumente presente nos médios e grandes templos, representado pelas indefectíveis livrarias e cantinas, deveria proceder à regularização de sua situação legal, mediante, por exemplo, o repasse de sua direção para empresários devidamente regularizados, com o intuito de evitar que as igrejas incorressem em ilegalidades fiscais passíveis de punição pelos poderes públicos.

Tomando o conjunto das mudanças previstas pela nova legislação, podem ser observadas importantes tensões e incompatibilidades entre as regras do novo Código e a organização e o funcionamento efetivo de diversas igrejas evangélicas, sobretudo pentecostais. Isso permite atentar para o quão significativas deveriam ser as mudanças perpetradas por muitas igrejas para se adaptarem às determinações legais. Por um lado, o novo Código proíbe

18 Eclésia, n. 85, 2003.p. 31.

19 Eclésia, n. 85, 2003, p. 36. 
que as associações aufiram lucro, exige que possuam contabilidade e declarem Imposto de Renda - ameaçando os faltosos com perda de isenções tributárias, confisco de bens e prisão -, estimula a democracia interna, coibindo abusos e aumentando o direito de defesa e o poder individual e colegiado dos associados. Por outro lado, vicejam em muitas igrejas evangélicas práticas conflitantes com o espírito e as disposições no novo Código. Casos, por exemplo, da intransparência na gestão e aplicação dos recursos arrecadados e na administração da denominação e de seu patrimônio; do incentivo à obtenção de lucro na gestão e direção da associação religiosa; do enriquecimento de líderes religiosos e de instituições religiosas sem fins lucrativos; do desvio de recursos coletados entre os fiéis para a compra, expansão e abertura de empresas; do nepotismo, do autoritarismo e da crescente verticalização do poder eclesiástico em diversas igrejas.

\section{A alteração do Código Civil: a bancada evangélica em defesa da liberdade religiosa}

Esse sofrimento durante esse ano, gerou uma coisa importante: a unidade. Porque todos viveram um ano de agonia e as divergências desapareceram, porque todos se uniram no sentido de buscar o maior status da Igreja que é a separação do Estado. Senador Magno Malta (PL-ES). ${ }^{20}$

Uma igreja não pode ser engessada por normas definidas pelo Estado, é inconstitucional. Não se pode tratar igrejas como uma associação de futebol do bairro" (Bispo Robson Rodovalho, líder da Sara Nossa Terra e presidente do Fórum Evangélico Nacional de Ação Social e Política - Fenasp). ${ }^{21}$

Em 2003, a reação evangélica ao Código Civil transmutou-se da submissão resignada à lei para a luta coletiva visando alterá-la no Congresso Nacional. A partir de então, deputados e senadores da bancada evangélica, em uníssono com suas lideranças eclesiásticas, tomaram a dianteira dessa reação, conduzindo-a pela via parlamentar.

A principal bandeira acionada pelos evangélicos para legitimar a luta política pela alteração do Código Civil foi a defesa da liberdade religiosa, a mesma hasteada por líderes e igrejas pentecostais para justificar o ingresso

\footnotetext{
20 www.walterpinheiro.com.br/palavra_lei_depoimentos.htm.

21 Correio Braziliense, 30 out. 2003, matéria intitulada "A pressão das igrejas".
} 
concertado na política partidária por ocasião da Constituinte (Mariano e Pierucci, 1992). Segundo esses religiosos, ao definir as igrejas como associações, o Código Civil (e, por conseqüência, o Estado) estaria embaraçando seu funcionamento, o que é inconstitucional e um flagrante atentado à liberdade religiosa. Na opinião do Deputado Federal Hidekazu Takayama (PSB-PR), autor de um dos projetos de lei para alterar o Código, embora a Constituição estabeleça "que não pode haver interferência nas igrejas. Regidas pelas normas das associações, elas ficarão à mercê das leis do Estado". ${ }^{22}$ David Tavares Duarte (2003, p. 19) não nutria dúvida alguma de que "a interferência do Estado no funcionamento da igreja e o excesso de poder outorgado ao associado [pelo Código] para intervir internamente na administração da mesma" ferem regras constitucionais vigentes.

No dia 2 de abril de 2003, o Deputado Federal Paulo Gouvêa (PL-RS), pastor da Igreja Universal, apresentou o Projeto de Lei 634/03 na Câmara dos Deputados propondo a alteração do Código Civil para incluir as entidades religiosas como pessoas jurídicas de direito privado. Na justificativa do referido Projeto de Lei, pioneiro nesse intento, afirma que as igrejas (ao lado dos partidos políticos) ficaram "numa espécie de limbo jurídico" no novo Código, por não terem sido definidas como pessoas jurídicas privadas, como ocorria no Código Civil anterior. Nos meses seguintes, os deputados evangélicos Philemon Rodrigues (Pmdb-MG), Costa Ferreira (PFL-MA), Hidekazu Takayama (PSB-PR), Lincoln Portela (PL-MG), Agnaldo Muniz (PPS-RO), Silas Câmara (PTB-AM), Eduardo Cunha (PPB-RJ), João Batista (PFL-SO) também elaboraram e apresentaram projetos de lei com objetivo semelhante, embora com redações e teores diversos.

Nos dois meses finais de 2003, por meio de intensa mobilização e pressão político-religiosa ao longo do ano, deputados e senadores evangélicos, apoiados por igrejas evangélicas e entidades católicas ${ }^{23}$ e ecumênicas, como Cnbb e Conic, conseguiram, finalmente, fazer aprovar a alteração do Código Civil na Câmara dos Deputados e no Senado Federal. Em 4 de novembro de 2003, a Comissão de Constituição e Justiça e de Cidadania da Câmara dos

Correio Braziliense, 31 out. 2003.

23 Cumpre observar que o Deputado Federal Severino Cavalcante (PP-PE), católico conservador, apresentou projeto de lei propondo que "a transformação de igrejas em associações seria facultativa e não obrigatória”, cf. Correio Braziliense, 30 out. 2003. 
Deputados aprovou o substitutivo elaborado pelo Deputado Federal João Alfredo (PT-CE), católico, classificando as organizações religiosas como pessoas jurídicas de direito privado. Em seu substitutivo aos projetos de lei apresentados pelos deputados evangélicos citados, João Alfredo inseriu as organizações religiosas e os partidos políticos como pessoas jurídicas de direito privado no Artigo 44, desobrigando-as, com isso, de alterar seus estatutos no prazo previsto pelo Artigo 2.031 da Lei n. 10.406, que institui o Código Civil.

Cabe fazer um parêntese para observar que, segundo o Deputado Federal João Alfredo (PT-CE), no relatório que apresentou na Comissão de Constituição e Justiça e de Redação da Câmara dos Deputados, definia as igrejas, do ponto de vista "técnico-jurídico", como associações:

O Código Civil de 1916 [...] não era preciso no que concerne à definição das pessoas jurídicas de direito privado; especialmente no inciso I do art. 16, o qual se referia às "sociedades civis, pias, morais, científicas ou literárias, as associações de utilidade pública e as fundações". Com efeito, não existia, em regra, a figura específica da "sociedade religiosa". Tratava-se de enumeração exemplificativa, dado que essas entidades, em regra, e com mais rigor técnicojurídico na definição de sua natureza jurídica, eram associações. [...] Assim sendo, as então denominadas "sociedades religiosas" não "desapareceram" com o novo Código, apenas passaram, corretamente, a serem consideradas como associações. [...] Tudo isto considerado, a síntese a que se pode chegar é a de que, a rigor, as entidades religiosas têm a natureza jurídica de associações, podendo, também, atuar como fundações. É certo dizer, todavia, que, pela sua natureza peculiar, não devem submeter-se, senão subsidiariamente, às normas que regem as associações, tais como postas nos arts. 59 a 63 do diploma civil. Há que se lhes aplicar estas regras com o temperamento necessário, a fim de a lei não se chocar com o texto constitucional - art. 19, I.

Aprovado na Comissão de Constituição, Justiça e Cidadania, o substitutivo do projeto foi para a Câmara dos Deputados. No dia seguinte, 5 de novembro de 2003, o Plenário da Câmara aprovou a emenda substitutiva global de Plenário, de autoria do batista e Deputado Federal Walter Pinheiro ${ }^{24}$ (PT-

24 Em setembro de 2003, os deputados Walter Pinheiro (PT-BA), Ary Vanazzi (PT-RS), Wasny de Roure (PT-DF), Gilmar Machado (PT-MG), Henrique Afonso (PT-AC) e Zico Bronzeado (PT-AC), representantes do Movimento Evangélico Progressista (MEP), formaram comissão legislativa e requereram a realização de audiência pública na Câmara dos Deputados para 
BA), ao Projeto de Lei 634/03, do Deputado Federal Paulo Gouvêa (PL-RS), dando nova redação aos artigos 44 e 2.031 do novo Código Civil. Novamente o relator da matéria foi o deputado João Alfredo (PT-CE), que proferiu parecer pela constitucionalidade, juridicidade, técnica legislativa e aprovação da emenda substitutiva global apresentada por Pinheiro. A tramitação, como ocorrera desde o final de outubro, sucedeu em regime de urgência por voto de liderança dos partidos. Com a palavra cedida pelo Presidente da Câmara dos Deputados antes da votação em Plenário, João Alfredo reconheceu que a emenda de Pinheiro aperfeiçoou seu substitutivo apresentado na Comissão de Constituição e Justiça, ao estabelecer a liberdade de criação, organização e estruturação interna e funcionamento das organizações religiosas "de maneira mais bem definida". Realçou ainda que o Código Civil, no estado em que se encontrava antes, "embaraçaria o funcionamento das organizações religiosas”, ferindo a Constituição Federal, que veda à União Federal, aos Estados, ao Distrito Federal e aos Municípios estabelecer cultos religiosos ou igrejas, subvencioná-los e embaraçar-lhes o funcionamento.

O substitutivo de Pinheiro, cumpre destacar, suprimiu trecho do Artigo $1^{\circ}$ do substitutivo de João Alfredo, apresentado na Comissão de Constituição, Justiça e Cidadania, que sujeitava as organizações religiosas e os partidos políticos, "subsidiariamente, às normas pertinentes às associações". Por conta disso, as disposições concernentes às associações deixaram de se aplicar, mesmo que subsidiariamente, às organizações religiosas.

Em seguida, o Projeto de Lei foi encaminhado ao Senado Federal, onde, no dia 3 de dezembro, foi aprovado pela Comissão de Constituição e Justiça, na qual atuaram os senadores evangélicos Magno Malta (PL-ES), Paulo Octávio (PFL-DF) e Marcelo Crivella (PL-RJ). Na semana posterior, dia 9 de dezembro de 2003, o Plenário do Senado ratificou sem alterações o Projeto de Lei da Câmara $n^{\circ}$ 88/2003, mantendo a definição das organizações religiosas e dos partidos políticos como pessoas jurídicas de direito privado. $\mathrm{O}$ pro-

debater o novo Código Civil brasileiro e as Igrejas. Tal iniciativa demonstra que a "esquerda evangélica" estava muito atenta às demandas de suas lideranças eclesiásticas e fortemente engajada nas articulações e movimentações da Frente Parlamentar Evangélica, presidida pelo Deputado Adelor Vieira (Pmdb-SC). Por sua iniciativa e proximidade com as lideranças do Governo no Congresso e no Executivo, entre outros motivos, o petista Walter Pinheiro, batista vinculado ao MEP, figurou como agente de proa na aprovação da alteração do Código Civil na Câmara dos Deputados, sendo autor da Emenda Substitutiva Global de Plenário. 
jeto teve como relator o Senador batista Magno Malta (PL-ES), para o qual as entidades religiosas, antes da referida alteração, estavam num verdadeiro "estado de pavor".

Nesse ponto da exposição da reação evangélica, deve-se atentar para o fato de que os deputados evangélicos empregaram, segundo admite o próprio Senador Magno Malta, a "estratégia" de "incluir os partidos políticos" na categoria de pessoas jurídicas de direito privado, "para poder aprovar essa mudança com a velocidade que aprovamos. Isso foi feito de forma consciente". ${ }^{25}$ Da mesma forma, o Deputado Estadual Edino Fonseca (Prona-RJ) corrobora o emprego da estratégia, realçando ainda o interesse das lideranças partidárias na composição da aliança: "o acordo político para a aprovação da emenda foi uma carona na mobilização popular dos evangélicos que os partidos políticos pegaram". "Porque se não os apoiássemos, eles não nos apoiariam", afirmou. ${ }^{26}$ A estratégia do tipo "toma-lá-dá-cá” articulada por dirigentes partidários e evangélicos foi bem-sucedida.

Pouco antes do Natal, em 22 de dezembro de 2003, o presidente da República, Luiz Inácio Lula da Silva, sancionou a Lei n ${ }^{\circ} 10.825$ (tal como aprovada na Câmara e no Senado), dando nova redação aos artigos 44 e 2.031 da Lei $\mathrm{n}^{\circ}$. 10.406, de 10 de janeiro de 2002, que instituiu o Código Civil. O Artigo $1^{\circ}$ da Lei $n^{\circ} 10.825$ decreta: "Esta lei define as organizações religiosas e os partidos políticos como pessoas jurídicas de direito privado, desobrigando-as de alterar seus estatutos no prazo previsto pelo art. 2.031 da Lei ${ }^{\circ}$ 10.406, de 10 de janeiro de 2002 - Código Civil”. No Artigo 44 do Código passou a constar parágrafo referente às organizações religiosas, estabelecendo: "São livres a criação, a organização, a estruturação interna e funcionamento das organizações religiosas, sendo vedado ao poder público negar-lhes reconhecimento ou registro dos atos constitutivos e necessários ao seu funcionamento". A ênfase predominante do parágrafo citado, como se pode inferir, recai na defesa da liberdade das organizações religiosas, ou, ainda, na disposição de reassegurar legalmente a liberdade religiosa frente ao poder do Estado.

25 Disponível em http://textoseideias.blogspot.com/.

26 Disponível em http://www1.uol.com.br/bibliaworld/jornalpalavra/codigo/9601.htm. 
$\mathrm{Na}$ cerimônia de sanção da nova lei, Lula discursou "para cerca de 150 religiosos, majoritariamente pastores evangélicos", tendo a fala pontuada por gritos de "glória a Deus". ${ }^{27}$ O Presidente da República referiu-se à Lei 10.825 como a "lei que torna livre a liberdade religiosa no país". Enfatizou que "durante muitos e muitos anos eu encontrava com pastores, pelo Brasil afora, que perguntavam para mim: "Lula, é verdade que se você ganhar as eleições você vai fechar as igrejas evangélicas?" Em resposta às velhas e injustas acusações, asseverou: "E quis Deus que, no primeiro ano do meu governo, a última lei que sanciono, no ano de 2003, é exatamente para dizer que aqueles que me difamaram agora vão ter que pedir desculpas, não a mim, mas a Deus e à sua própria consciência." Reafirmando seu compromisso com a liberdade religiosa, a qual dispôs ao lado das liberdades política e sindical como um dos principais pilares da democracia moderna, concluiu: "E fico mais feliz, ainda, quando posso no dia 22 , às $16 \mathrm{~h}$, na frente de padres, bispos, pastores, deputados da comunidade religiosa brasileira, dizer para vocês: se alguém tinha dúvida, a dúvida acabou. É livre o direito de organizar uma Igreja e de praticar sua religião". Nas eleições de 2006, Lula, em várias ocasiões, procurou tirar proveito eleitoral da sanção da lei que alterou o Código Civil, relembrando sistematicamente os evangélicos, durante encontros, comícios e em material da campanha presidencial, de que ele assegurou a liberdade religiosa no Brasil.

O presidente Lula justificou a sanção da nova lei com base nos mesmos termos e argumentos empregados pelos evangélicos: a alteração do Código Civil (para incluir as organizações religiosas como pessoas jurídicas) visa defender e assegurar a liberdade religiosa, que supostamente estava ameaçada pelo próprio estado brasileiro. Também presente na cerimônia, Márcio Thomaz Bastos, Ministro da Justiça, adotou a mesma interpretação sobre o significado legal da alteração do Código Civil, ao declarar: "O Estado está proibido de tomar qualquer decisão que proíba o funcionamento das entidades religiosas". Noutro depoimento, o Ministro tratou a mudança na lei como a correção de "um grave defeito do Código Civil". ${ }^{28}$

Vários líderes evangélicos deram depoimentos com teor relativamente semelhante aos de Lula e do Ministro da Justiça sobre a Lei 10.825:

27 Folha de S. Paulo, 23-12-2003.

28 www.walterpinheiro.com.br/palavra_lei_depoimentos.htm. 
Nilson do Amaral Fanini, presidente da Convenção Batista Brasileira: "Com essa nova lei, a igreja continua com toda a liberdade para adorar a Deus, louvar a Deus, para fazer missões e para evangelizar, e para fazer obras sociais". ${ }^{29}$

Pastor Isaías Andrade Lins Filho, presidente da Convenção Batista Baiana: "A decisiva e inquestionável participação direta do Deputado Federal Walter Pinheiro preencheu de maneira extremamente clara uma lacuna que não poderia deixar de ser preenchida, haja vista que o preceito constitucional contido no inciso I, do art. 19, da Constituição Federal já estabelecia total liberdade de culto para toda e qualquer religião, fato este que não foi levado em consideração pelos insignes legisladores quando da elaboração dos dispositivos do art. 44 e seguintes do novo Código Civil’."

Sóstenes Borges de Sousa, presidente do Ministério Internacional do Salvador: "A reforma do novo Código Civil consolidou o texto constitucional no que diz respeito à liberdade religiosa no Brasil e nos resgatou do grande erro do novo Código que se omitia totalmente em relação à expressão de fé da nação". ${ }^{31}$

Roberto Brasileiro Silva, presidente do Supremo Concílio da Igreja Presbiteriana do Brasil: "Reconhecemos o esforço conjunto do Deputado Walter Pinheiro, do MEP e demais lideranças na condução do projeto de lei que permitiu as igrejas retomarem a sua liberdade de organização e estarem devidamente inseridas no novo Código Civil brasileiro agora na forma da lei 10.285. Cremos que a visão demonstrada por ele engrandece a nossa casa de leis e leva-nos de fato a reconhecermos que estamos vivendo um novo tempo político onde a nossa democracia está evoluindo para alcançar a sua maturidade". ${ }^{32}$

Os depoimentos concedidos ao site do deputado Walter Pinheiro, além de enaltecê-lo, destacam a vitória da liberdade religiosa sobre o "grande erro" do Código e a desatenção dos legisladores. Deixam implícito, porém, o "adversário" a ser contido para que pudessem reassegurar sua liberdade. Em entrevista ao Jornal União, o Senador Magno Malta (PL-ES) dá "nome aos bois", destacando o forte temor dos evangélicos em relação a qualquer tipo de "interferência" do estado nas igrejas. O fato é que nesse e noutros relatos os evangélicos avaliaram a necessidade da alteração do Código visando defender a liberdade religiosa contra o poder e a ação estatais, mais especificamen-

\footnotetext{
29 www.walterpinheiro.com.br/palavra_lei_depoimentos.htm.

30 www.walterpinheiro.com.br/palavra_lei_depoimentos.htm.

31 www.walterpinheiro.com.br/palavra_lei_depoimentos.htm.

32 www.walterpinheiro.com.br/palavra_lei_depoimentos.htm.
} 
te contra a possibilidade de atuação da Justiça e, em especial, do Ministério Público sobre as organizações religiosas. Assevera o senador Malta:

O nosso país, o Brasil, é um país laico. O Brasil não tem religião oficial. Aqui nós temos liberdade de culto garantida pela Constituição Federal, em qualquer lugar, seja praça pública ou não. Em sendo assim, nós temos liberdade enquanto entidade religiosa, temos estatutos e regulamentos próprios, sem que a mão do Estado esteja sobre a Igreja, pois não há mais religião oficial. Então, o novo Código Civil tratava as igrejas como um Clube de futebol, uma associação qualquer, e o indivíduo que a ela pertence não é membro, mas é sócio, correto? E aí, as ofertas, por exemplo, a partir de 10 de janeiro agora, se nós não tivéssemos feito essa emenda que derrubou essa medida do Código Civil, teriam que ser depositadas no banco - e não poderiam ser dadas na igreja - senão ia caracterizar caixa dois. O dízimo tinha que ir para o depósito lá. O sujeito que se desligasse da associação poderia ir na Justiça e requerer o seu dízimo de volta. Agora você imagine o Ministério Público em cima da igreja. O Estado em cima da igreja. Nós perderíamos todas essas garantias que nos são dadas pela Constituição Federal. Mais que isso: do ponto de vista espiritual não há a menor condição que haja envolvimento ou intervenção do Estado sobre a igreja. Então, eu reputo que a mudança no Código Civil, que atormentou durante um ano as igrejas e colocou as entidades religiosas desesperadas no país, tenha sido a maior vitória da igreja no ano de $2003 .{ }^{33}$

Diversos líderes eclesiásticos e políticos evangélicos se apresentaram ou foram declarados co-responsáveis pela aprovação da alteração do Código Civil no Congresso Nacional. Independentemente do oportunismo de vários deles, a mobilização evangélica foi coletiva, articulada e contou efetivamente com a participação e o apoio de muitos pastores, bispos, entidades e igrejas. Ao lado dos parlamentares evangélicos que participaram na elaboração, apresentação, votação e aprovação do referido projeto de lei, engajaram-se nessa mobilização pastores e líderes eclesiásticos, consultores jurídicos e políticos da Convenção Geral das Assembléias de Deus no Brasil (Cgadb), da Convenção Nacional de Ministros das Assembléias de Deus de Madureira (Conamad), das Convenções batistas, da Universal do Reino de Deus, da Presbiteriana do Brasil, da Metodista, da Evangelho Quadrangular, da Sara Nossa Terra, do Conselho Nacional de Igrejas Cristãs (Conic), da Frente Parlamentar Evangélica, do Movimento Evangélico Progressista (MEP), do

33 http://textoseideias.blogspot.com/. 
Fórum Evangélico Nacional de Ação Social e Política (Fenasp), do Grupo de Assessoria Parlamentar Evangélica (GAPE), entre outros. Além disso, cumpre lembrar que, nessa empreitada, os evangélicos contaram com o apoio e a participação da Conferência Nacional dos Bispos do Brasil (Cnbb) e da bancada católica na Câmara dos Deputados.

Esse episódio demonstra novamente a elevada capacidade dessas lideranças eclesiásticas para mobilizar as bases pastorais, parlamentares e de fiéis por meio do acionamento de uma identidade de minoria religiosa discriminada e sob risco iminente. ${ }^{34}$ Empenhados na defesa dos interesses e bandeiras de suas igrejas, seus representantes políticos procuram fazer jus às demandas de suas bases eleitorais e, ao mesmo tempo, superar a concorrência dos demais candidatos evangélicos pelo apoio oficial das hierarquias denominacionais. O episódio comprova também que as lideranças evangélicas aprenderam de uma vez por todas a encaminhar e resolver seus problemas, religiosos ou não, "por cima", isto é, arregimentando sua representação político-partidária para defender as causas de seu interesse corporativo, mesmo que em oposição à normatividade jurídica. Como frisou Silas Malafaia, pastor e televangelista da Assembléia de Deus: "Nós estamos compreendendo que como segmento social nós temos o direito de reivindicar e de marcar posição. Então, esse ato demonstra nossa força e também o entendimento do governo em relação à força da comunidade evangélica no país". 35

Essa força política e religiosa, por certo, deverá ser demonstrada inúmeras vezes, sobretudo se se considerar que ela granjeia parte considerável de sua robustez, eficácia e visibilidade por ser disputada avidamente por partidos e candidatos de todos os matizes ideológicos a cada eleição e em um sem-número de votações nos legislativos do país. O toma-ládá-cá, tão bem exemplificado pelos apoios recíprocos entre os líderes partidários, o presidente/candidato Lula e as lideranças eclesiásticas e parlamentares evangélicas, à medida que resulta, para os partícipes dessas

34 Cumpre frisar que essa identidade revela-se bastante ambígua, configurando-se distintamente conforme o contexto, os interlocutores, interesses e discursos em jogo. Haja vista que também assume características diametralmente opostas, ora dotada de feições triunfalistas, ora de ares de superioridade de quem se vê na condição de ungidos do Senhor e detentor do monopólio da verdade e da salvação divinas.

35 www.walterpinheiro.com.br/palavra_lei_depoimentos.htm. 
alianças e relações de barganha, em ganhos eleitorais, em conquista de recursos públicos, em parcerias com o Governo, em concessões de emissoras de rádio e $\mathrm{TV}$ etc., só tende a reforçar a inserção e participação desses religiosos na esfera pública e na política partidária.

\section{Referências}

BURITY, Joanildo A. Religião e política na fronteira: desinstitucionalização e deslocamento numa relação historicamente polêmica. Revista de Estudos da Religião, São Paulo, n. 4, p. 27-45, 2001.

DUARTE, Cícero Augusto Gonçalves. Igrejas na mira da lei. São Paulo: Bompastor, 2003.

DUARTE, David Tavares. A igreja e o novo Código Civil: as mudanças e outras considerações jurídicas sobre a prática eclesiástica. Rio de Janeiro: Cpad, 2002.

FONSECA, Alexandre Brasil. Evangélicos e mídia no Brasil. Dissertação (Mestrado em Sociologia) - Ifcs-Ufrj, Rio de Janeiro, 1997.

- Secularização, pluralismo religioso e democracia no Brasil. Um estudo sobre evangélicos na política nos anos 90. Tese (Doutorado em Sociologia) - FflchUSP, São Paulo, 2002.

FRESTON, Paul. Protestantes e política no Brasil: da Constituinte ao impeachment. Tese (Doutorado em Sociologia) - Ifch, Unicamp, Campinas,1993.

GARCIA, Gilberto. O novo Código Civil e as igrejas. São Paulo: Editora Vida, 2003.

GIUMBELLI, Emerson Alessandro. O fim da religião: controvérsias acerca das "seitas" e da "liberdade religiosa" no Brasil e na França. Tese (Doutorado em Antropologia Social) - Museu Nacional, Ufrj, Rio de Janeiro, 2000.

HORTAL, Jesús Sánchez. Religião, liberdade e controle. Veredas. Belo Horizonte, v. 1, n. 1, p. 87-93, 2000.

MAINWARING, Scott. Igreja Católica e política no Brasil (1916-1985). São Paulo: Brasiliense, 1989.

MARIANO, Ricardo. Neopentecostais: sociologia do novo pentecostalismo no Brasil. São Paulo: Edições Loyola, 1999.

—. Análise sociológica do crescimento pentecostal no Brasil. Tese (Doutorado em Sociologia) - Fflch, USP, São Paulo, 2001.

MARIANO, Ricardo; PIERUCCI, Antônio Flávio. O envolvimento dos pentecostais na eleição de Collor. Novos Estudos Cebrap, n. 34, p. 92-106, 1992.

NOVO CÓDIGO CIVIL BRASILEIRO. São Paulo: Ed. Escala, s. d. 
PEREIRA, Odilon Alexandre Silveira Marques. O novo Código Civil e a igreja: Impactos e implicações. Londrina: Instituto Jetro, 2003.

PIERUCCI, Antônio Flávio. Representantes de Deus em Brasília: a bancada evangélica na Constituinte. Ciências Sociais Hoje, 1989. São Paulo: Vértice / Revista dos Tribunais, Anpocs, p. 104-132, 1989.

. Liberdade de cultos na sociedade de serviços. In: PIERUCCI, Antônio Flavio; PRANDI, Reginaldo (Orgs.). A realidade social das religiões no Brasil: religião, sociedade e política. São Paulo: Hucitec, 1996. p. 275-285.

ROLIM, Francisco Cartaxo. Pentecostais no Brasil: uma interpretação sócio-religiosa. Rio de Janeiro: Vozes, 1985.

Recebido em $1^{\circ}$ de agosto de 2006 e aprovado em 28 de setembro de 2006 